\title{
The Early Śaiva Matha: Form and Function
}

\author{
Libbie Mills
}

We should begin by determining what we think a matha to be in the early Śaiva context. In the seventh and eighth centuries, mathas began to receive royal patronage. By the ninth and tenth centuries mațas collected taxes and agricultural profits (Sears 2014, 6). In the later period and in the south, mathas come to be a place for pilgrims passing through, or an institution for professional adepts, a place one might abide in on a hereditary basis. There is a rise in endowments for mathas in the eleventh and twelfth centuries, with the head of the matha perhaps being the rājaguru, the royal guru, of the dominion, hence a figure of political importance (Nandi 1987, 194-195).

But the matha of the earlier Śaiva world is at base something simpler. It is a place for an initiate to stay in for an extended period for the purposes of study, as an áśramin. It is housing for initiated students, with a guru offering teaching. Brunner-Lachaux (1998, 380), describing the situation as given in the Somaśambhupaddhati, tells us: "Celui dont Somaśambhu parle (et qu' il nomme áśrama en sp1, p. 316) est d'abord un lieu où vivent des initiés de différents grades, sous la conduite matérielle et spirituelle d'un guru." This was not a shelter for itinerant ascetics, not a locus of political power, but both a residence and a school for initiates or, in Sanderson's $(1988,681)$ terms, a lodge for cult lineage members.

Next, let us look more closely at these matha residents. The residents are initiated āśramins assigned, as Brunner-Lachaux described, into four levels according to their type of initiation. The samayin has received the samaya $d \bar{\imath} k s \bar{a}$, the initiation for the pledge-holder or neophyte, and is qualified to study the teachings. The putraka has received the nirvāna dīkșā and will thus be liberated at the moment of death. The ācārya has received the consecration for officiants (ācārya abhișeka) and is qualified to teach and give dīkșā. And the sādhaka has received the sādhaka abhiṣeka and is qualified to practice rituals in order to obtain supernatural powers.

As we see stated at Mohacürottara 4.243, all these initiates, at whatever their level, are further regarded as being veritable lingas, "markers" or sacred images, of Śiva. They are mobile ( jangama) lingas, as opposed to the fixed (ajangama or sthāvara) lingas which are images installed permanently in a temple. To establish either is an act of great piety: 
saṃsthāpya sthāvaram lingaṃ prāsāde yad bhavet phalam tat phalam labhate vidvān mațhe saṃsthāpya jangamam 243

The reward that a wise man gains from establishing a mobile image (jaingamam lingam) [i.e. an ascetic] in a matha is the same as the reward that he gains from establishing a fixed image (sthāvaram lingam) in a temple. (243)

Having found the residents to be initiates of different types, all considered to be mobile lingas, let us think about their initiation into that role, and why one might build a matha for them.

If the adept is a mobile linga, is, then, his dīkșa (initiation) equivalent to the pratisthth (installation) of an immobile linga, an image in a temple? The matter has been considered by, among others, Hikita (2005, 193), and Mori $(2005,232)$; the latter observes that pratisțha $\bar{a}$ brings the deity into a fixed linga, while dīkșa does the same thing into a mobile one. As Mori $(2005,202-$ 203) notes from the twelfth-century Vajrāvalī of Abhayākaragupta: "and [the ācārya] carries out also the installation of an image, etc., like the installation of a disciple (śisyapratișthām iva pratimādipratișthām kuryāt)." Mori goes on to demonstrate that "in actuality there are many correspondences between the installation and consecration ceremonies." Given that dīkșa (initiation of an adept) and pratișth $\bar{a}$ (installation of an image) are parallel processes, the place of installation, the home for the initiate, is important, just as the temple, the shelter for a fixed image, is a place of consequence.

If the place has consequence, then there should be a reward from its establishment. An immobile linga is installed in a private shrine for the benefit of the commissioning sädhaka. What of the installation of a mobile linga, an adept, in a matha? Who benefits from that? What is the incentive? As we saw above, the Mohacūrottara states at 4.243 that the installation of a mobile linga in a mața brings merit to the patron who commissions and funds it. So we here move on from the idea of installation of an immobile linga in the private shrine, for the benefit of the sädhaka patron, to something else, to a linga that can move about, but must still be installed and housed, bringing reward to the patron who houses it.

In looking for accounts of this housing for adepts, I am drawing upon six early Śaiva records, the same six on which Professor Sanderson worked with me some two decades ago (for a study published recently as Mills 2019): the Kirana, Devyāmata, Pingalāmata, Brihatkālottara, Mayasamgraha, and Mohacūrottara. I will go through what we can learn about the matha from these texts. We will find the most useful material in the Mohacurrottara (1oth- or 11th-century) and 
Devyāmata (in which the prāsādalakșaṇa material shows signs of being substantially earlier; see Mills 2019).

\section{$1 \quad$ Housing in General}

To begin, I should give a very brief outline of how these texts describe building plans for houses in general: normal housing, not maț has in particular. The texts give accounts of the elevation, the vertical design, that are easily followed. But descriptions of the plan, the horizontal design, rely on some basic background knowledge, which I now supply.

Measurements are made in hastas, hands, a measure from the elbow to the tip of the middle finger of the patron. Those measurements are checked for their a aya. The a ayas are formulae used to test measurements, to ensure that they are suitable for use. A common presentation is of six sets of āyas: āya, vyaya, řșa, yoni, vāra, and tithi or aṃśa. There are 12 āyas in a list of items beginning with siddhi; 10 ryayas in a list of items beginning with śikhara; 27 r $k s ̦ a$ s in a list of the naksatras; 8 yonis in the list of 8 that is dhvaja, etc.; 7 väras in a list of the days of the week; 30 tithis in a list of the lunar days in a month; and 9 amśas in a list of items beginning with taskara. In each list, some members are regarded as auspicious, some as inauspicious.

The measurement to be tested is multiplied by a set number. The product of that multiplication is then divided by the number of items in the a ay a set. The remainder is checked against the corresponding $\bar{a} y a$ in the set to determine whether the measurement is suitable or not. Let me give an example: in the yoni àya list, the listed yonis are numbered from 1 to 8. Dhvaja (flag) is 1, dhüma (smoke) is 2, simha (lion) is 3, śvan (dog) is 4, vrșabha (bull) is 5 , khara (donkey) is 6, gaja (elephant) is 7 and khaga (bird) is 8 . The yonis with an odd number are regarded as auspicious. Those with an even number are considered inauspicious. A measurement to be checked against the yoni ayas is multiplied by the number 3 . The product is then divided by the number of yonis, 8 . If the remainder is 1 , the yoni aya for that measurement is dhvaja, which is auspicious; if it is 2 , the yoni a yya for that measurement is dhuma, which is inauspicious, and so on. Each yoni âya, from dhvaja onward, is associated with a planet, and also with the cardinal and intermediate directions from the east onwards in a clockwise direction, according to the positions assigned to those planets. Below, we will see these associations used to indicate directions in house construction.

Moving now from measurements to design, the plan for the construction is always in the form of a square. That square is divided into a grid of cells (padas), with the same number of cells along each side. In the pattern that we 


\begin{tabular}{|c|c|c|}
\hline 1 Brahmā & 16 Jaya & $3_{1}$ Dauvārika \\
\hline 2 Marīcaka & 17 Mahendra & $3^{2}$ Sugrìva \\
\hline 3 Vivasvant & 18 Sūrya & 33 Puspadanta \\
\hline 4 Mitra & 19 Satya & 34 Pracetas \\
\hline 5 Prthividhara & 20 Bhrrśa & 35 Asura \\
\hline $6 \bar{A} p a$ & 21 Antarikṣa & 36 Śoṣa \\
\hline 7 Āpavatsa & 22 Agni & 37 Roga \\
\hline 8 Savitr & 23 Pūṣan & $3^{8}$ Vāyu \\
\hline 9 Sāvitri & 24 Vitatha & 39 Nāga \\
\hline 10 Indra & 25 Gṛhakșata & 40 Mukhya \\
\hline 11 Indrajit & 26 Yama & 41 Bhallāṭa \\
\hline 12 Rudra & 27 Gandharva & 42 Soma \\
\hline 13 Rudradāsa & 28 Bhrriga & 43 Rgi \\
\hline $14 \overline{I s} s a$ & 29 Mrga & 44 Aditi \\
\hline${ }_{15}$ Parjanya & 30 Pitr & 45 Diti \\
\hline
\end{tabular}

$\mathrm{N}$

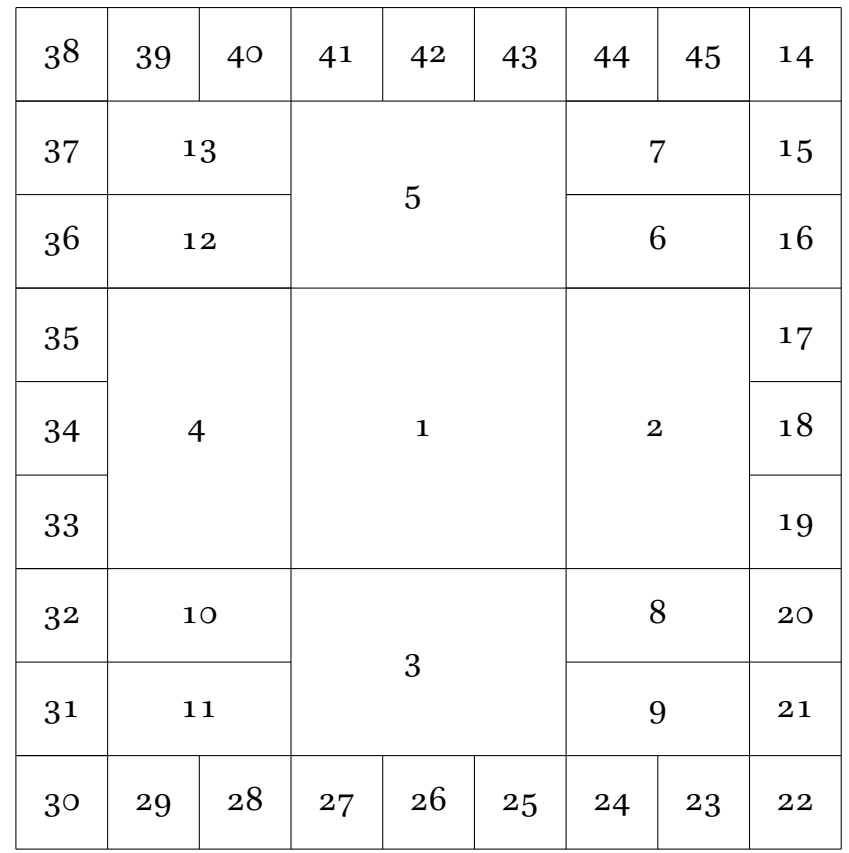

FIGURE 20.1 The $9 \times 9$ plan, Brhatkälottara, chapter 112 (the vāstuyāgapațala) 
$\mathrm{E}$

\begin{tabular}{|c|c|c|c|c|c|c|c|c|}
\hline $\begin{array}{l}\text { İsa } \\
\text { Krttika } \\
\text { bhaya }\end{array}$ & $\begin{array}{l}\text { Parjanya } \\
\text { Pūrva- } \\
\text { phālgunī } \\
\text { stricalatva }\end{array}$ & $\begin{array}{l}\text { Jaya* } \\
\text { Jyeșthā } \\
\text { vijaya }\end{array}$ & \begin{tabular}{|l} 
Māhendra ${ }^{*}$ \\
Višákhā \\
śri
\end{tabular} & $\begin{array}{l}\text { Sürya } \\
\text { Punarvasu } \\
\text { pratäpakrt }\end{array}$ & $\begin{array}{l}\text { Satya } \\
\text { Aśleșa } \\
\text { dharma }\end{array}$ & $\begin{array}{l}\text { Bhrśa } \\
\text { Hasta } \\
\text { kalaha }\end{array}$ & \begin{tabular}{|l|} 
Kha \\
Ārdrā \\
sūnya
\end{tabular} & $\begin{array}{l}\text { Agni } \\
\text { Anurāadhā } \\
\text { dāha }\end{array}$ \\
\hline $\begin{array}{l}\text { Diti } \\
\text { Uttarabhadrā } \\
\text { hrāsa }\end{array}$ & & & & & & & & $\begin{array}{l}\text { Pūssan* } \\
\text { Visákhhā } \\
\text { sukha }\end{array}$ \\
\hline $\begin{array}{l}\text { Aditi } \\
\text { Dhanissthā } \\
\text { āyuhksayaa }\end{array}$ & & & & & & & & $\begin{array}{l}\text { Vitatha } \\
\text { Revati } \\
\text { duhkha }\end{array}$ \\
\hline $\begin{array}{l}\text { Śravana } \\
\text { Sravana } \\
\text { dainya }\end{array}$ & & & & & & & & $\begin{array}{l}\text { Grhaksata } \\
\text { Müla } \\
\text { mrtyu }\end{array}$ \\
\hline $\begin{array}{l}\text { Soma* } \\
\text { Mrgasîrșka } \\
\text { sampatkara }\end{array}$ & & & & & & & & $\begin{array}{l}\text { Yama } \\
\text { Bharañì } \\
\text { ksaya }\end{array}$ \\
\hline $\begin{array}{l}\text { Bhalvāta * } \\
\text { Abhijit } \\
\text { dhana }\end{array}$ & & & & & & & & $\begin{array}{l}\text { Gandharva* } \\
\text { Pūrvāsasadhā } \\
\text { sušslatā }\end{array}$ \\
\hline $\begin{array}{l}\text { Mukhya* } \\
\text { Uttarabhadra } \\
\text {-ka } \\
\text { pradhānatva }\end{array}$ & & & & & & & & $\begin{array}{l}\text { Bhrńngadeva } \\
\text { Aśvinì } \\
\text { dainya }\end{array}$ \\
\hline $\begin{array}{l}\text { Nāga } \\
\text { Svâti } \\
\text { kandarpa }\end{array}$ & & & & & & & & $\begin{array}{l}\text { Mrgaa } \\
\text { Citrā } \\
\text { aśri }\end{array}$ \\
\hline $\begin{array}{l}\text { Anila } \\
\text { Assăădha } \\
\text { uccātana }\end{array}$ & $\begin{array}{l}\text { Roga } \\
\text { Tisya } \\
\text { roga }\end{array}$ & $\begin{array}{l}\text { Sossa } \\
\text { Aśvinin } \\
\text { soṣa }\end{array}$ & \begin{tabular}{|l|} 
Asura \\
Śata(bhisaj) \\
Arthaksaya
\end{tabular} & $\begin{array}{l}\text { Varuna* } \\
\text { Rohinī } \\
\text { śașada }\end{array}$ & $\begin{array}{l}\text { Puspadantaka } \\
* \\
\text { Uttara- } \\
\text { phālguñ } \\
\text { vrddhida }\end{array}$ & $\begin{array}{l}\text { Sugrīiva* } \\
\text { Pūrvāsaădhā } \\
\text { krșisaukhya }\end{array}$ & \begin{tabular}{|l|} 
Dauvāri \\
Pūrva- \\
bhadraka \\
vratabandha
\end{tabular} & $\begin{array}{l}\text { Pitr } \\
\text { Maghā } \\
\text { anāyusya }\end{array}$ \\
\hline
\end{tabular}

FIGURE 20.2 Deity, nakșatra, and consequence of door position. Brhatkālottara, prāsādalakșanapațala $238 \mathrm{c}-243 \mathrm{~b}$. Positions with an asterisk are those recommended in $243 \mathrm{c}-245^{b}$

will see here, the pattern for the construction of housing, as opposed to temples or funerary grounds or other things, there are 9 cells along each side of the square, producing a grid of 81 cells in total. See figure 20.1 as an example from the Brhatkālottara of such a configuration. Once these padas have been laid out, deities are installed in them. In the most common pattern 45 deities are installed. 32 of those deities are placed in the 32 padas around the outer edges of the plan, and 13 deities are placed inside that framework, with Brahmā at 
the very centre. When building houses, particular attention is paid to the consequences of a doorway placed at any of the 32 padas around the periphery. See figure 20.2 for an example of an account of doorway consequences, again from the Brhatkālottara.

This fundamental 9-by-9-part deity map is used as the basis for plans of greater or lesser complexity. For housing, we will see descriptions of three types of design.

The most involved, which I will call type 1, is the design for a 9-by-9-part pura, a residential complex for a community and its lead figure. That lead figure might be a king or a lesser noble, an important functionary such as a general, or a guru. Other members of the community and all the functions of community life are arranged on the 81 cells of the 9-by-9 plan just described, with careful specifications as to what should be placed in each cell of the periphery in particular.

Here is an account of a type 1 complex from the Mayasamgraha, 5.156-159 and 181-187 (between verses 159 and 181, the text digresses to describe mandapas and column types):

\begin{tabular}{|c|}
\hline $\begin{array}{l}\text { nata1 vișkambhamānena kṛtasīmni mahītale } \quad{ }^{156} \\
\text { añkvādinā orhānīśapadādīni prakalpavet }\end{array}$ \\
\hline $\begin{array}{l}\text { tatraiśe japahomārcādhāmopaskaraṇānvitam } 157 \\
\text { parjanye sarvavādyāni² vidheyāni vipaścitā }\end{array}$ \\
\hline $\begin{array}{l}\text { snānārghasādhanaṃ vastu jayante marubhṛnmukhe }{ }^{3} \quad 158 \\
\text { traye pratolī saddvārakapāțārgalaśobhitā }\end{array}$ \\
\hline $\begin{array}{l}\text { maṇdapaś ca vibhūtyarthaṃ geyanātyādisiddhaye } 159 \\
\text {.. }\end{array}$ \\
\hline $\begin{array}{l}\text { rúāāditritaye kuryāt pākasthānaṃ yathepsitam } \\
\text { șṇi bhojanabhāṇṇāni vitathe salilāśrayaḥ } 181 \\
\text { lanuḥkhaḍgaśarāinini vidadhyāt tu gṛhakṣate }\end{array}$ \\
\hline
\end{tabular}

1 156c mata ] em.; matetyādi C; mano A

2 158a ${ }^{\circ}$ vādyāni ] C; 'opākāni A

3 158d obhrno ] C; 'tvan A 
gandharve gāyakasthānaṃ bhụnge vyākhyānasaṃśrayaḥ ${ }^{4}$ snānadhāma mṛgasthāne koṇe śaucagṛhaṃ tatạ̣ 183 mațham vā vipulaṃ kuryād gṛhakṣatacatușțaye tāmbūladantakāșțhādidhāma dauvārike ${ }^{5}$ hitam $\quad 184$ sugrīve puṣpadante ca pracetasi ca bhojanam abhyāgatāśrayaṃ kuryād vidvān asuraśoșayoḥ $\quad 185$ muṣalolūkhalakumbhaśilāyantrādikaṃ ruji gandhasthānaṃ gandhavahe puṣpāyanam ahitraye 186 somadvaye kośagṛhaṃ vidyādhāmāditidvaye brahmādiṣu padeșv antar amarālayamaṇḍapạ̣ ${ }^{6} \quad 187$

This record lists a place for worship at İśa; music at Parjanya; ritual bathing and offering at Jayanta; a gateway at Indra, Sūrya and Satya (marubhrnmukhe traye); the kitchen at Bhṛśa, Antarikṣa and Agni (bhrśäditritaye); eating vessels at Pūșan; a water tank at Vitatha; a store room at Gṛhakșata; a place for ascetics to achieve contemplation of the self (samyāminām sthānam àtmālokanasiddhaye) at Yama; singers at Gandharva; a place for teaching the śāstras (vyākhyānasaṃśrayah) at Bhṛnga; bathing at Mṛga; toilets at Pitr (kone); betel, etc., at Dauvārika; food storage at Sugrīva, Puṣpadanta and Pracetas; a room for visitors at Asura and Śoṣa; tools at Roga (ruji); perfumes at Vāyu (gandhavahe); flowers at Nāga, Mukhya and Bhalvāța (ahitraye); the treasury at Soma and Rgi (somadvaye); and a school (vidyādhäma) at Aditi and Diti (aditidvaye). Within this framework, at Brahmā, etc., are a temple and maṇdapa. At Gṛhakșata, Yama, Gandharva and Bhrngaa, a mațha is introduced as an alternative at 184ab.

\section{Type 2: The 5-by-5 nandyāvarta / nandikāvarta}

A second design, somewhat less elaborate, is termed the nandyāvarta or nandi$k \bar{a} v a r t a$. This serves as a simpler residence to house higher-ups—nobility, army generals, and gurus - and their households. In this case, laid over the fundamental 9-by-9-part deity map is a building design of 5 parts by 5 parts, with spacing between chambers that produces an array of nine chambers in total, or eight if the central position is left undesignated. Each of the eight or nine chambers is assigned a function. See figure 20.3 for some examples of these $5^{-}$ by-5 designs.

4 183b osamśrayah ] em.; 'saṃśraye A

5 184d dauvārike ] em.; daurike A

6 187d maṇdapah ] C; maṇdalam A 


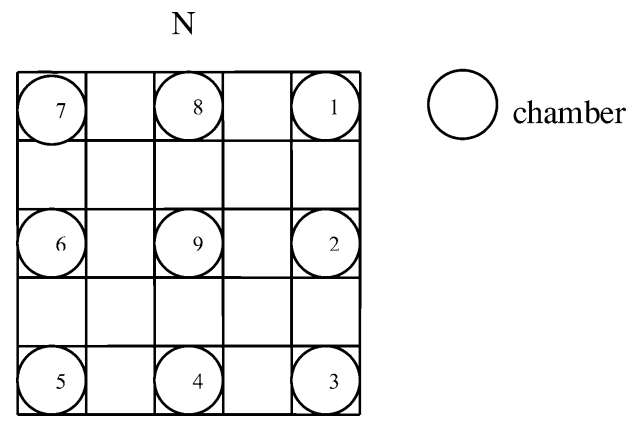

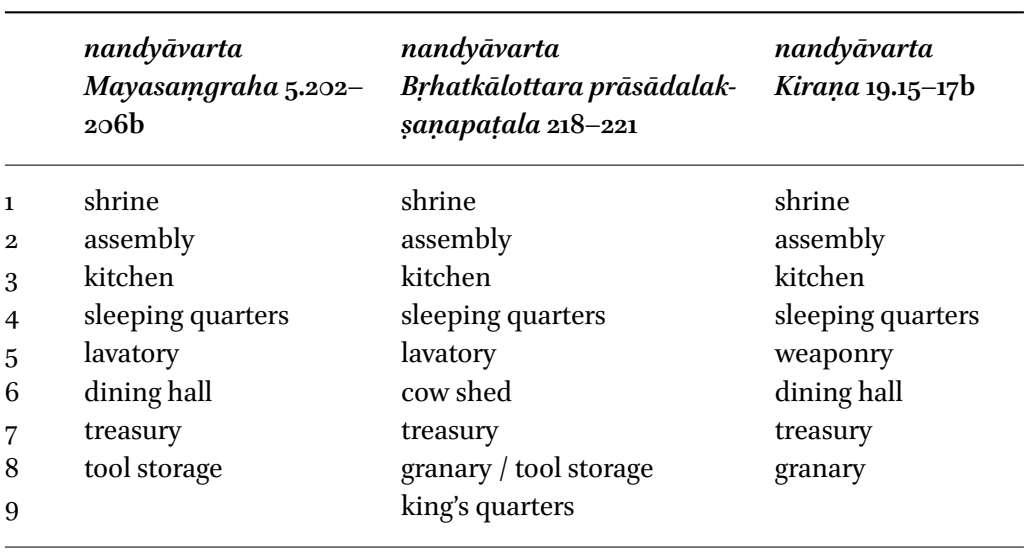

FIGURE 20.3 The nandyāvarta/nandikāvarta set of nine chambers

Take for example the description of a type 2 design from Pingalämata 10.96c-114b:

aștasáālayutaṃ dhanyaṃ nandikāvartam ${ }^{7}$ ucyate $\quad 96 \mathrm{~cd}$ àyacakraṃ vibhajyādau śālāsādhanahetukam pūrve tu śrịgṛhạ̣ kuryād dhvajāyena vipaścite $\quad 97$ yāmye śayyāg̣̣haṃ proktaṃ siṃhāyena vijānatah paścime bhojanaṃ gehaṃ vṛsāyena ${ }^{8}$ vidur budhāḥ $\quad 98$ nyāsaṃ gṛhottare kuryād gajāyena na saṃśayah dhūmāyena prakartavyaṃ pākaṃ dahanagocare ${ }^{9} \quad 99$ pāyudaṃ pitarasthe tu śvanāyena na saṃśayah

7 96d nandikāvartam ] AC; vandikāvarttam B

8 98d vṛsāyena ] BC; vṛșayena A

9 99d dahana ${ }^{\circ}$ ] AC; hadahana B • ogocare ] BC; ogocaram A 
dhānyādikṣodanaṃ gehaṃ vāyavyāṃ rāsabhena tu 100 yāgamaṇḍapa aiśānyāṃ dhvāṅkṣāyena tu sundari munitārākareṇaiva rudras tridaśa eva ca 101 daśapañcakareṇaiva daśasaptadikchaktikam ekaviṃśatkarenaiva dhvajāyaṃ pūrvato bhavet 102 caturaśraṃ samantāt tu kartavyạ̣ śrīg̣̣hottamam ${ }^{10}$ tatra sthāne sadā bhadre ${ }^{11}$ śrīmantraih saha saṃyutạ̣ ${ }^{12} \quad 103$ śriyam tatra likhet ${ }^{13}$ sākṣāc chrīgṛhaṃ tena cocyate ekona ${ }^{14}$ viṃśahastena pūrvapaścāyatam ${ }^{15}$ bhavet 104 daśasaptakareṇaiva vistarạ̣ dakṣiṇottaram siṃhāyam ca bhavet tena dakṣiṇe śayanāśrayaḥ ${ }^{16} \quad 105$ daśapañcakareṇaiva sadīrgham dakṣiṇottaram rudrasaṃkhyākareṇaiva vistaraṃ pūrvapaścimam 106 vṛṣāyaṃ ca bhavet tena paścime bhojanāśrayah trayodaśakareṇaiva pūrvapaścāyatam kuru 107 rudrasaṃkhyākarenaiva dakṣiṇottaravistaram gajāyaṃ jāyate tena bhāṇ̣̄āgārottareṇa tu 108 daśāṣțakaradīrghaṃ tu vistareṇa trayodaśạ dhūmāyaṃ jāyate tena vahnau pākaṃ vidur budhāḥ $\quad 109$ pradīrghaṃ daśahastam tu șaṭkaram vistareṇa tu śvānāyam jāyate tena pițsthāne tv avaśyakam 110 daśahastam bhaved ${ }^{17}$ dairghyam ${ }^{18}$ svaravad vistaram priye kharāyam jāyate ${ }^{19}$ vasyaṃ vāyavyāṃ kaṇḍanīg̣̣ham ${ }^{20} \quad 111$ dvirașțakaradairghyaṃ tu dviṣațkaṃ vistaram priye dhvāṅșāyaṃ jāyate 'traiva aiśānyāṃ yāgamaṇḍapạ 112 śrīg̣̣he ${ }^{21}$ vāthavā tam tu viṣamạ̣ caturaśrakam vittānusārato budhvā coktā nyūnādhikaṃ bhavet 113 tṛtīyaṃ nandikāvartạ̣ cumbakasya prakīrtitam 114ab

103b ogrhottamam ] BC; ogrhottamah A

103c bhadre ] BC; bhadraih A

103d samyutah ] BC; saṃyutaị̣ A

104a likhet ] C; likșet AB

104c ekona ${ }^{\circ}$ ] A; ekonam C; ekūnam B

104d 'opaścāyatam ] A; ${ }^{\circ}$ paścāyaṃ BC

105d śayanāśrayah ] A; sayanāyayam BC

111 a bhaved ] AC; bhave B

111a dairghyam ] BC; dīrghyam A

111c jayate ] AC; jayante $B$

111d kaṇḍnīgṇham ] BC; kaṇdaṇīg̣̣hī A

11зa śrīgṛhe ] A; g̣̣he BC 
This account lists the eight chambers of the nandikāvarta for a cumbaka as follows: the assembly chamber is in the east, the sleeping quarters are in the south, the dining hall in the west, the treasury in the north, the kitchen is in the southeast, the lavatory in the southwest, the granary in the northwest, and the shrine in the northeast. For each chamber, the correct a aya proportion is assigned.

The third, lowest, level of complexity produces housing for normal citizens, graded according to either caste or initiation class. Here we see a design, again laid over the basic 9-by-9 deity map, for a residence with only four rooms, or three, two, or one, in descending order according to levels of caste or initiation.

An example of a type 3 presentation for different initiation levels is given at Pingalāmata 10.93-95 and 114c-128 (verses 96-114b cover the Nandikāvarta, as seen above):

sāmānyaṃ saṃpravakṣyāmi cumbakādyāśrayaṃ priye svakṛtānyakṛtāṃ ${ }^{22}$ vāpi śālāṃ caivādhunā śṛ̣u 93 catuhśālaṃ triśālaṃ ca dviśālaṃ caikaśālakam śālāsaṃkhyā bhavanty ${ }^{23}$ etā vibhāgas tv adhunocyate ācāryasya catuhśsālaṃ triśālaṃ ${ }^{24}$ sādhakasya tu putrakasya dviśālaṃ ca samayī hy ekaśālakaḥ ${ }^{25} \quad 95$ $\cdots$ svastikāvartam anyac ca tasyaiva catuhśáālakam 114cd vittahīno yadā bhadre tadā tat kathayāmi te sayāgāsthānapūrve ${ }^{26}$ tu sapākaśayanāntake ${ }^{27} \quad 115$ sapātribhojanaṃ cāpye sayantranyāsam uttare ${ }^{28}$ yady asya samnnikṛștam tu taddiśāyāṃ prakalpayet $\quad 116$ taddiśāya yutaṃ caiva kalpanaṃ g̣̣havarjitam

\footnotetext{
22 93c svakṛtānyakṛtāṃ ] A; svakṛtānyakṛtam BC

23 94c bhavanty ] AB; bhavaty C

2495 b triśālaṃ ] AB; triśāla $C$

2595 d ekaśālakah ] em.; ekeśālakam ABC

26115 c sayāgāsthāna ${ }^{\circ}$ ] A; sayāgasthāna ${ }^{\circ} \mathrm{BC} \cdot{ }^{\circ}$ pūrve ] A; ${ }^{o}$ pūrvaṃ BC

27 115d ósayanāntake ] AB; 'samayāntake C

28 116b uttare ] AB; uttaram C
} 


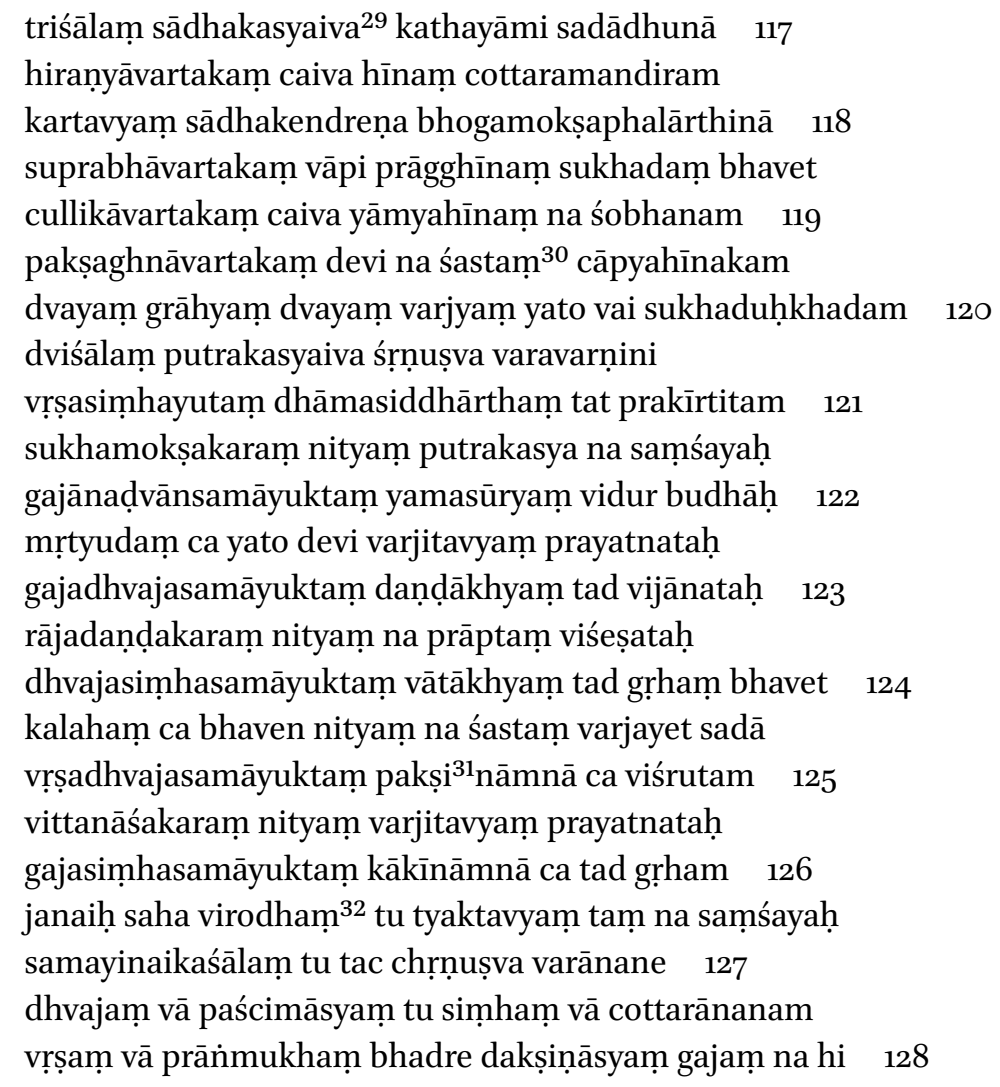

In verse 10.95 we are told that the house for an ācärya has four rooms, that for a sādhaka has three, and that for a putraka has two, while the samayin has one room. The verses from 114cd onward describe the four-roomed, three-roomed, two-roomed and one-roomed house. In the case of the four-roomed one, recommended for the cumbaka when money is wanting, we are given an account of the rooms at $115 \mathrm{~cd}-116 \mathrm{ab}$. The shrine is in the east, the kitchen and bedroom are in the south, the vessel store and dining room are in the west, and the utensils and treasury are in the north. In the case of the three-roomed house for the sādhaka, we are told that there may be a room lacking in the north or in the east, but not in the south or in the west. The house with no room in the north

$29117 \mathrm{c}$ sādhakasyaiva ] em.; sādhakaścaiva ABC

$30 \quad 120$ b śastam ] A; saptam BC

31 125d pakșio ] BC; pakṣī A

32 127a virodham ] A; virodhe BC 
is termed the hiranyanäbha, while that without a room to the east is termed a suprabhävartaka. In the case of the 2-roomed and 1-roomed house, the direction of the rooms is described in terms of the 8 ay a direction associations, from dhvaja in the east onwards in a clockwise rotation.

Having looked at accounts of construction of housing in general, in types 1, 2 and 3, we now are ready to look at what the texts have to say about mațas in particular. The Brhatkālottara and Kirana give details on the design of temples and also on the construction of domestic buildings for different members of society, from kings down to ordinary caste members. But these texts do not refer to a mațha or anything that could be understood as a matha.

The Mayasamgraha mentions the mața, but quite briefly. As we saw above, Mayasamgraha 5.156-159 and 181-187 describes the pura on a 9-by-9-plan, listing the uses to which each of the 32 padas around the outskirts of the plan is put: kitchen, storage areas, armories, meeting rooms, etc., in a type 1 design. On reaching those padas at the centre of the south side, the text tells us that:

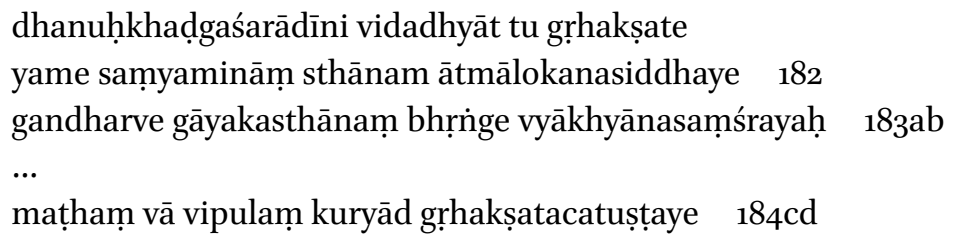

At Gṛhakșata one should set up [a storeroom for] bows, arrows, swords, and other weapons. At Yama there should be a place for ascetics to achieve contemplation of the self (samyāminām sthānam ātmālokanasiddhaye). Singers are stationed at Gandharva. At Bhrnga is a hall for the exposition [of the śästras]. Or one may construct a large mața on the four [positions] which are Gṛhakșata and [Yama, Gandharva and Bhṛnga].

Here, the Mayasamgraha is giving the matha as an option, to be placed on the south edge of a pura, as an alternative to a combination of items: weapons, ascetics, singers, and a space for teaching. Why here, on the south side? Bakker $(2004,118)$ has pointed out that the south, a direction associated with the inauspicious, with death, is also viewed as being the benign right side of the deity or guru as he faces east. Thus it is a suitable position for the initiate, at the right side of the deity or guru. 
The Pingalämata, in chapter 10, verses 3-77, in describing a 9-by-9 type pura, lists the uses to which each of the 32 padas all around the outskirts of the plan are used. In verses $33^{-3} 6$ the Pingalämata, like the Mayasamgraha, places the mața on the south side, at the padas of Yama and Gandharva.
yame gandharvake kuryān mațhaṃ bhūmitrayānvitam $33 \mathrm{~cd}$ athavā dvayasārdhaṃ tu bhūmikaikāthavā priye uttamaṃ madhyamaṃ caiva kanyasam ca yathākramam 34 ācāryasya tad evoktam nijaṃ śayanahetukam iṣțāhnikaṃ jayaṃ dhyānaṃ yogābhyāsaṃ tu tatra vai vīrabhojyānnapānādyair vīraị̣ saha samācaret $\quad 36 \mathrm{ab}$

My dear, at Yama and Gandharva one should make a mața with three storeys, two [storeys] or one storey. [These are] the best, middling and least [mațhas] in turn. That is the place for the ācārya to sleep, for [prognostication of] auspicious days, triumph, meditation, and the practice of yoga. [There the teacher] may associate with viras (viraih saha), sharing vira food and drink, etc. ${ }^{33}$

Altogether, so far, from the Pingalāmata and Mayasamgraha, we have learned that the mațha is generally placed in the south. The Mohacürottara and Devyāmata give more information on the nature of the construction itself. The Mohacūrottara uses the term mața. The Devyāmata does not.

First let us look at what the Mohacūrottara has to say. At Mohacūrottara 4.234-243 we get a more detailed depiction of the mața:

mațhaś cāntakadigbhāge lingināṃ sthitaye hitah yatas te dakṣināásāyāṃ vaseyuḥ śivabhāvitāḥ $\quad 234$ prāsādavistaraṃ sūtraṃ tanmānaṃ jagatībahị prākāram kārayet tyaktvā tataś cāśramiṇāṃ gṛham 235 mațhāgre tatsamaṃ tyaktvā siṃhāyaṃ dakṣine sthitam vṛ̦āyam ${ }^{34}$ paścime jñeyam dhvajāyam ${ }^{35}$ pūrvatah sthitam $\quad 236$ vipulaṃ vā prakartavyaṃ kartur icchāvaśena tu

33 Shaman Hatley notes that "Vīra likely refers to sādhakas: 'heroic sādhakas' might be a good rendering. Vìrapāna refers to impure liquids such as alcohol, used in rituals of the Bhairava- and Kulatantras."

$34 \quad 236 \mathrm{c}$ vrșāyam ] F; vṛṣoyaṃ H

35 236d dhvajāyam ] F; dhvajeyam $\mathrm{H}$ 
caturaśre śarair bhakte madhyaṃ tyaktvā vilopayet 237

g̣̣hānāạm svecchayā nyāsaḥ saumye syād veśanirgamạ̣

ekabhaumaṃ dvibhaumaṃ vā tribhaumaṃ vā yathāsukham $\quad 238$

dīrghaśālāvṛtaṃ bāhye prāci yāgālayānvitam

pākādig̣̣havinyāsaṃ yathāyogaṃ niveśayet 239

pūrvoktam antaraṃ sārdhaṃ ${ }^{36}$ tasyāpy ardhaṃ yathāyatham

mațhikaikātrałyaṃ kāryaṃ† paț̣aśāā catuṣkikā $\quad 240$

bhūmayaḥ pūrvam uddișțā vittābhāve kuṭi matā

samasūtram susaṃsthānaṃ vāstupūjāpuraḥsaram $\quad 241$

lingināṃ ca gṛhaṃ kāryaṃ mahāpunyajigịṣayā

etad ${ }^{37}$ eva mahāpuṇamụ kathayāmi tavākhilam $\quad 242$

saṃsthāpya sthāvaraṃ lingam prāsāde yad bhavet phalam

tat phalaṃ labhate vidvān maṭhe saṃsthāpya jangamam 243

And a mața for ascetics to stay in (linginām sthitaye) should be in the south. For they, as devotees of Siva, should reside to the right [of Siva]. (4.234)

One should build a wall ( prākāram) at a distance 1 temple-width beyond the temple base (jagatī). At a distance from there (tyaktvā tatah) is the housing for ascetics (äśraminām gṛama). (4.235)

In front of the mațha (mațāgre), leaving a distance of the same [size] (tatsamam tyaktvā), [houses should be built that are sized according to] the simhaya in the south, the vrșayya in the west, and the dhvajaya in the east. (4.236)

Or they may be made as large as the patron wishes. They are on a square site divided into five [parts along each side]. One should leave the intermediate spaces empty (madhyam tyaktvā vilopayet). (4.237)

The installation of the houses is according to the wishes [of the patron]. There should be a [door for] entry and exit to the north. [The houses] may have one, two, or three floors, or as is pleasing. (4.238)

Externally, [the building] is surrounded by a long hall $(s \bar{a} l \bar{a})$. In the eastern side of the building is the place for worship (yāgālaya). One should install the kitchen and so forth as appropriate. (4.239)

At a distance of $1^{1 / 2}$-times the previously given distance, and half that, as is suitable, is a single mațhikā, in the form of a set of four (catușkikā) awnings (pațtaśālā). (4.240)

$36 \quad$ 240a sārdham ] em. Sanderson; sārdhaṃ Ātmārthapūjāpaddhati; cārddhạ̣ FH 
The storeys (bhümi) are as have already been taught. If money is lacking, a hut (kuțī) is approved. (4.241ab)

One should build the dwelling for ascetics with the same measurements and a good design, [and] performing the veneration of the site ( $v \bar{a} s-$ tupūja $)$, out of a desire to attain great merit. I will now describe to you this great merit in full. $(4.241 \mathrm{~cd}-242)$

The reward gained from establishing a mobile image (jangamam lingam) [i.e., an ascetic] in a matha is the same as the reward gained from establishing a fixed image (sthāvaram lingam) in a temple. (4.243)

So, here, we seem to have a matha housing complex to the south of the temple, bracketed to the east, south and west by actual residences. Verse 237 indicates that each individual residence is of the 5 -by- 5 type 2 variety. The term mathika is introduced, referring to a set of 4 awnings, and a simple hut, kuțī is given as a cheaper alternative.

And, finally, in Devyāmata, chapter 105 we are given another account of the residence for initiates. The terms used for the residence are grha (verses 1, 15, 17), āśrama (verses 15, 17), and veśman (verse 41). The term mața is not used. The terms used for the residents of these domiciles are āśramin (verse 1), prāsādāśramin (verse 82), dīkșita (verses 16, 17), grhin, and grhamedhin (verse 72). In verses $15^{-19 b}$ is given an account of the residence (grha) for the initiate (dikșita), outside the temple exterior wall and to the south of the temple:

dakṣiṇāyāṃ diśi śastaṃ gṛham āyatanasya tu prākārasya bahị̣ kāryam āśramāyatanasya tu ${ }^{38} \quad 15$ vastavyam lingam āśrtya dīkṣitaiḥ sujitendriyaih tadabhāve 'thavānyasmiṃ pradeśe sumanorame $\quad 16$ nātidūrāmbhasạ̣ kāryam āśramaṃ dīkșitātmanāṃ asaṃkīrṇẹ śubhe deśe vastavyaṃ dīkṣitātmabhị̣ 17 ekaśālaṃ dviśālaṃ vā triśālam athavā gṛham catuhśâāag̣̣haṃ vāpi kāryaṃ vittānusāratạ̣ 18 kāryaṃ hiraṇyanābham vā sukṣetram vā manoramam 19ab

A residence (grham) is recommended to the south of the temple. The residence (ásramam) should be built beyond the outer wall of the temple. (15)

38 Sanderson, by email communication, points out that the sense intended is certainly āśramam āyatanasyatu. 
It is to be dwelt in by initiates (dìkșitaih), their senses well-subordinated, who have come to (áśrtya) the image (lingam). Or, in its absence (tadabhāve), [they should dwell in] another pleasant place (pradeśe sumanorame). (16)

The residence (āśramam) for the initiates (dīkșitātmanām) should be built not too far from water. Initiates (dīkșitātmabhih ) should live in a fine, unpolluted place. (17)

The residence (grham) should have one, two, or three rooms. Or a fourroomed residence should be built, according to funding. (18)

A pleasing hiraṇanābha or sukșetra ${ }^{39}$ may be built. (19ab)

In verse 18 , the housing described is of type 3 . In verses $54-74 \mathrm{~b}$ the consequences of a doorway at each of the peripheral padas of the 9 by 9 deity map are given in some detail:

evaṃ yathākrameṇaiva dvārāṇāṃ phalam ucyate īśe hy agnibhayaṃ vidyāt parjanye strīviṣo gṛhī 54 jaye ca dhanasampanno māhendre nụpavallabhạ krodhaparas tathāditye satya rta $^{40}$ paro bhavet 55 bhṛ́se tasya bhavet krauryaṃ cauryaṃ caiva tathāmbare alpasutas tathā cāgnau pūṣākhye preșyatāṃ vrajet $\quad 5^{6}$ vitathe 'vinītatām yāti gṛhī gṛhakṣate sudhī yame ca raudratāṃ yāti gāndharve śrīm avāpnuyāt 57 bhṛngarāje bhaven nisvo mṛākhye ${ }^{41}$ ṇ̣papịditah uktạ̣ dvārāṣțakaṃ tubhyaṃ gṛhe 'smin dakṣiṇāmukhe $\quad 5^{8}$ procyate saviśeșeṇa g̣̣he 'smim paścimāmukhe paścime pitṛdevatye gṛhī syāt sutapīditaḥ ${ }^{42} \quad 59$ ripuvṛddhis tathā tasya vidyā dauvārike pade sugrīve dhanasampat syād gṛhiṇaḥ sarvadā bhavet $\quad 60$ sutārthabalasampat syāt pade 'smim puṣpadantake vāruṇe dhanasampattim nụpabhayaṃ tathāsure $\quad 61$

39 As recorded, for example, in Bṛhatkālottara, prāsādalakșaṇapațala 223-224 and Kiraṇa 19.18-19, the hiranyanäbha is a building with three rooms, in the east, west and south, and the sukșetra is a building with three rooms, in the west, south and north. At Pingalämata 10.118-119 (above), the building without a room in the north is termed a hiranyanäbha, while that without a room to the east is termed a suprabhāvartaka.

$40 \quad$ rta ${ }^{\circ}$ ] em.; nrrta ${ }^{\circ}$ MW; nanrmịta N. The emendation to $r t a$ is supported by the fact that at Bṛatkālottara, prāsādalakșaṇapațala 239 we see dharma at Satya.

$41 \quad 58 b$ mrgākhye ] em.; mrṣākhye NM; mṛ̣ākhya W

4259 d sutapịditah ] N; sutapātitạ̣ MW 
dhanakṣayam tathā śoṣe rogah syāt pāpayakșmaṇi aștau devāḥ samākhyātā gṛhe 'smin paścimāmukhe 62 vāyavyādikrameṇaiva procyate hy uttarāmukhe baddhabandhas tathā roge ripuh syān nāgasaṃjñike $\quad 63$ mukhye sutārthalābham syāt sampad bhalvāțake tathā dhanasampat tathā some putravairam anantake 64 strīdoṣaś cāditau jñeyo daridrā g̣̣hiṇo ditau kathitāni viśeșeṇa svadevatānvitāni tu 65 hitāvahitāni yāni syūr dvārāṇi śṛnu yatnatah jayākhyam yat tṛtīyaṃ tu suprabhūtadhanapradam 66 māhendrākhyaṃś caturthaṃ tu gṛhiṇāṃ sarvakāmikam ${ }^{43}$ gṛhakṣataṃ caturtham tu g̣̣he 'smin dakșināmukhe $\quad 67$ bhakṣyapānasutavṛ̂ddhiṃ karoti g̣̣hamedhinām gandharvākhyam tathā ṣașṭam śrīsaukhyaś ca sukhapradam 68 dvāradvitayam śașțaṃ hi g̣̣he 'smin dakșināamukhe dhanasampatkaraṃ dvāram tṛtīyam paścimāmukhe 69 caturthaṃ puṣpadantākhyaṃ sutārtha ${ }^{44}$ balavardhanam pañcamaṃ vāruṇaṃ dvāraṃ dhanasampatkaraṃ ṇ̣ṇām $\quad 70$ dvāratṛtayam ākhyātaṃ g̣̣he 'smin paścimāmukhe mukhyādhidevataṃ dvāraṃ tṛtīyam cottarāmukhe $\quad 71$ dhanasutārthasampattiṃ karoti g̣̣hamedhinām bhalvāțākhyaṃ caturthaṃ tu g̣̣hiṇāṃ sarvakāmadam $\quad 72$ dhanasampatkaraṃ proktam pañcamam somadevatam evaṃ jñātva $\bar{a}^{45}$ viśeșeṇa yathoktaṃ ${ }^{46}$ dvāralakṣaṇam $\quad 73$ guṇādhikaṃ ${ }^{47}$ tato vidvān sthāpayed dvāram ādarāt $\quad 74 \mathrm{ab}$

Thus, in due sequence, the consequences (phalam) of doorways are given. [With a doorway] at İ́a, the householder will have the risk of fire; at Parjanya, harm from women. (54)

At Jaya [the householder] is endowed with wealth. At Māhendra he is dear to the king. At Āditya there is anger. At Satya there is lawful conduct. (55)

At Bhṛśa is awfulness. And at Ambara there is theft. At Agni there is a lack of sons. At Pūṣan is servitude. (56)

67b sarvakāmikam ] em.; sarvakarmikam N; sakāmikam MW 7ob sutārtha ${ }^{\circ}$ ] MW; sutākhyam N

$45 \quad 73$ c jñātvā ] N; jñāna MW

46 73d yathoktam] N; yathoktā MW

47 74a guṇādhikaṃ ] N; gaṇādhikan M; gaṇādhika W 
At Vitatha the householder comes to a lack of decorum, at Gṛhakșata he gains wisdom. At Yama he attains savagery. At Gāndharva he acquires glory. (57)

At Bhṛngarāja there is malady. At Mrga one is oppressed by the king. The set of 8 doorways have been described to you, in the house facing south. (58)

Next it will be specifically described for the house facing west. In the west, at the Pitrdeva position, the householder will be oppressed by his sons. (59)

There is an increase in the enemy and his knowledge at Dauvārika. At Sugriva is always an increase of wealth for the householder. (6o)

At Puṣpadantaka is a gain in sons, wealth and power. At Vāruṇa is an increase in wealth. At Asura is danger from the king. (61)

There is loss of wealth at Śoṣa and disease at Pāpayakșman. Eight deities have been listed, in the house facing west. (62)

Those facing north are listed next, in sequence, from the northwest (vāyarya) on. At Roga is bondage. At Nāga (Vāsuki) is an enemy. (63)

At Mukhya is an increase in sons and wealth. At Bhalvāṭa is gain. At Soma is a gain in wealth. At Anantaka is heroism in sons. (64)

At Aditi is trouble from women. At Diti is poverty. Specifically listed with their own deities are those doorways which are especially good. Listen with care. The third one, named Jaya, brings great power and wealth. $\left(65^{-66)}\right.$

The fourth one, named Māhendra, fulfills every desire for the householder. The fourth one in the house facing south, Gṛhakșata, increases food, drink and sons for householders. The sixth one, called Gandhārva, brings glory, pleasures and contentment. (67-68)

The second set of doorways has been declared, on the south side. On the west side, the third doorway (i.e., at Sugriva) brings an increase in wealth. (69)

The fourth, called Puspadanta, increases sons, power and strength. The fifth doorway, Vāruna, brings increased wealth for men. (70)

The third set of doorways has been declared, on the west side. And on the north side, the doorway governed by Mukhya brings an increase in wealth, sons and property to householders. The fourth one, named Bhalvāța, gives men every desire. $\left(71^{-72}\right)$

The fifth one, whose deity is Soma, brings an increase in wealth. After learning the features of doorways as described, specifically, the wise man should carefully establish a doorway with ample good qualities. $\left(73^{-74 a b)}\right.$ 
One should note that, while these are the consequences for doorway positions in a residence for ascetics, the consequences do not fall on the ascetic residents themselves, but on the patron who commissions and funds the building of the residence, and who gains the benefit from it. ${ }^{48}$ So, the consequences are not in any way to be connected to the lives of the residents. None-the-less, it is worth noting that these are the same consequences that we see repeated over and again for domestic buildings of all sorts. The model that is being used is that for normal housing.

The portion from 81 to 86 describes the layout of the residence ( $g r h a)$ for the prāsādāśramin:

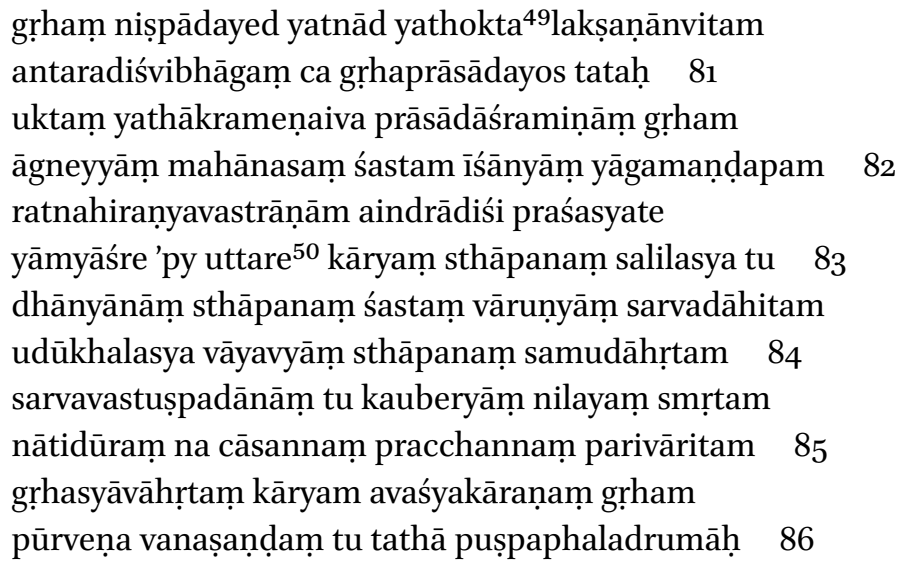

One should carefully arrange the residence (grham) in such a way that is has the characteristics that have been taught. Then [one should arrange] the area in between (antaradiśvibhägam) the residence and temple. (81)

The residence for those who come to the temple (prāsādāśrami$n \bar{a} m)$ is described in due sequence. In the southeast is the kitchen (mahānasam). In the northeast is the space for worship (yāgamandapam). (82)

Storage for gems, gold and cloths (ratnahiranyavastrānām) is recommended in the east, and for water in the south and centre. ${ }^{51}(83)$

48 I thank Shaman Hatley for this observation.

49 81b yathokta ${ }^{\circ}$ ] MW; antaram N

50 83c yāmyāśre 'py uttare ] MW; yāmyāśreruttare N

$5^{1}$ I take uttare to refer to the position to the north of the southern cell. That is, the centre. I 
Grain storage (dhānyānām) is recommended in the west. In the northwest is storage for the mortar (udükhalasya). (84)

To the north is general storage (sarvavastușpadānām). Not too far away (nātidūram), nor adjoining (na cāsannam), is a secluded (pracchannam), sheltered (parivāritam) (85)

lavatory building (avaśyakāranam gṛam), aside from the residence (grhasyā $\bar{a} h r$ rtam). To the east (pürvena) should be made a copse (vanașaṇdam), and trees with flowers and fruit (pușpaphaladrumāh). (86)

This is an account of a type 2 nandikāvarta type of construction, with 8 rooms on a 5 -by-5 plan.

From verse 87 on we get a detailed description of the trees for the surrounding gardens. Then the chapter ends:

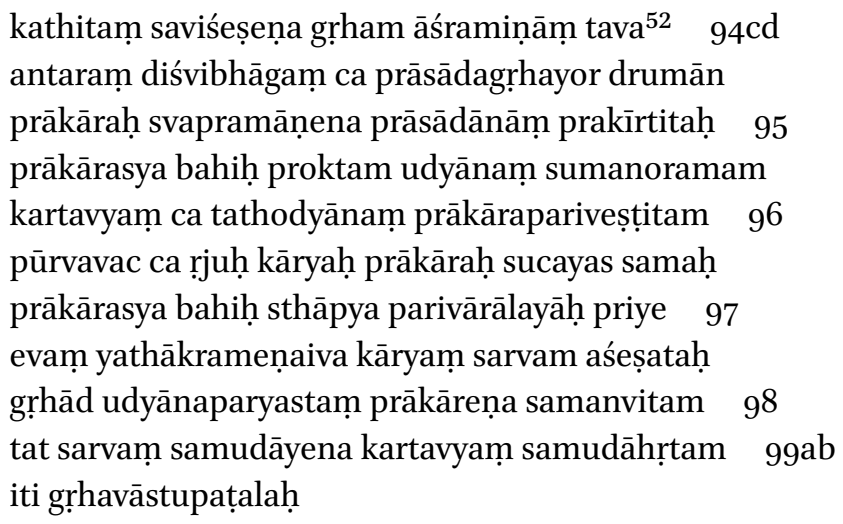

The residence (grham) for the āśramins has been described to you in particular; (94cd) and [also] the intervening (antaram) area (diśvibhāgam) between the temple and residence (prāsādagrhayoh), and trees. The surrounding wall ( präkārah), with its measurements, has been described for temples. (95)

The pleasing garden (udyānam) beyond the surrounding wall has been described. The garden too is to be surrounded by a wall (prākāraveștitam). (96)

find support in the fact that, in verse 22 of this chapter, we were informed that the water supply should be in the centre of the house (grhamadhye). 
As before, the surrounding wall should be made straight, well erected and level. My dear, having established the subsidiary shrines (parivāràlayāh) beyond the wall, (97)

everything should be made thus, complete, and in due sequence.

Beyond the residence, it is surrounded by a garden and has a surrounding wall. Everything to be done has been altogether declared. (98-99ab)

Thus ends the chapter on the residence.

Looking back over what we have seen, in the Brhatkälottara and Kiraṇa we saw no mention of a mațha, but from the Mayasamgraha and Pingalāmata came the information that the matha should be on the south side. When it came to details of the mațha design, we saw in the Mohacūrotttara and Devyāmata descriptions that looked very much like those for houses for any other person, in types 2 and 3 , to the south of a type 1 complex.

We have been looking at the building designs for clues as to what went on inside them, following the sensible line of thinking of Sears $(2014,76)$, who writes, "the architecture of the monastery indexes the concerns of its residential community." But perhaps all we have learned from the building designs for the matha is that dorms are dorms, in the end. While the installation of a jangama linga, an initiate, is equal in merit to the installation of an ajarigama linga, an image, there is by no means the same glamour in its housing. This proves to be a practical domestic establishment entirely like that of an altogether ordinary person who is not initiated—not a jangama linga.

\section{Acknowledgment}

My gratitude to Professor Sanderson is enormous. His guidance is invaluable in many ways, but I will point out just two. On the one hand there is his stern search for error in the material, on the other is his patient tolerance of error in the student - a tolerance that I put to some pretty severe testing, of course. None of this work would have been possible without it.

\section{References}

\section{Primary Sources}

\section{Kiranatantra}

Dominic Goodall, ed. Bhațtarāmakanțhaviracitā Kiranavrttiḥ. Bhaț̣a Rāmakanțha's Commentary on the Kiranatantra. Volume I: Chapters 1-6. Critical Edition and Anno- 
tated Translation. Publications du département d'indologie, no. 86.1. Pondichéry: Institut français de Pondichéry/École française d'Extrême-Orient, 1998.

Śrimat-Kiraṇāgama-mahātantram. Pañcāpageśa śivācārya and K.M. Subrahmaṇyaśā-

strī, eds. Devakoțtai: Śivāgamasiddhāntaparipālanasanghha, 1932.

NAK 5-893; NGMPP reel no. A40/3.

NAK 4-13; NGMPP reel no. B117/11.

IFP T. no. 47637.

IFP T. no. 39802 .

IFP T. no. 998.

IFP T. no. 0746.

IFP T. no. 0401.

\section{Devyāmata}

(N) NAK 1-279; NG MPP reel no. A 41/15.

(M) NAK 1-1003; NGM PP reel no. B 27/6.

(W) Wellcome Institute, gamma 6o7.

\section{Pingalāmata}

(A) British Library OR 2279

(B) NAK 3-376; NGMPP reel no. A42/2

(C) NAK 5-1929; NGMPP reel no. A166/5

\section{Bṛhatkālottara}

NAK 1-273; NGMPP reel no. B24/57

NAK 1-89; NGMPP reel no. B24/59

NAK 5-778vi; NGMPP reel no. A $42 / 8$

NAK 5-4632; NGMPP reel no. B118/7

NAK 4-131; NGMPP reel no. A43/1

\section{Brhatsaṃhitā of Varāhamihira}

Avadha Vihārī Tripāṭhī, ed. Bṛhatsaṃhitā of Varāhamihira with the Commentary of Bhațtotpala. Varanasi: Varanaseya Sanskrit Vishvavidyalaya, 1968.

M. Ramakrishna Bhat, ed., trans. Varāhamihira's Bṛhatsamihitā, 2 vols. Delhi: Motilal Banarsidass, 1981, 1982.

Kṛ̣̣nacandra Dvivedī, ed. Bṛhatsaṃhitā by Śrī Varāhamihira with Commentary of Bhațtotpala. Varanasi: Sampurnanand Sanskrit University, 1996.

\section{Mayasamgraha}

(A) NAK 1-1537; NGMPP reel no. A31/18

(C) A copy of a commentary to the Mayasamgraha: the Bhāvacūdāmaṇi of Bhațța 
Vidyākantha. Shri Raghunath Temple Manuscript Library no. 5291, now in the collection of the Ranbir Research Institute, Jammu.

\section{Mohacūrottara}

(F) NAK 1-1633; NGMPP reel no. B26/29

(G) NAK 4-1622; NGMPP reel no. B27/18 (missing the section of chapter 4 discussed here).

(H) NAK 5-1977; NGMPP reel no. A182/2.

\section{Somaśambhupaddhati}

Hélene Brunner-Lachaux, ed. 4 volumes. Collection Indologie, nos. 25.1-4. Pondichéry: Institut Français de Pondichéry, 1963, 1968, 1977, 1998.

\section{Secondary Sources}

Bakker, Hans. 2004. "At the Right Side of the Teacher: Imagination, Imagery and Image in Vedic and Śaiva Initiation." In Images in Asian Religions: Texts and Contexts, edited by Koichi Shinohara and Phyllis E. Granoff, 117-149. Vancouver, B.C.: University of British Columbia Press.

Granoff, P.E. 2004. "Images and their Ritual Use in Medieval India: Hesitations and Contradictions." In Images in Asian Religions: Texts and Contexts, edited by Koichi Shinohara and Phyllis E. Granoff, 19-55. Vancouver, BC: University of British Columbia Press.

Hikita, Hiromichi. 2005. "Consecration of Divine Images in a Temple." In From Material to Deity, Indian Rituals of Consecration, edited by Shingo Einoo and Jun Takashima, 143-198. Manohar: New Delhi.

Mills, Libbie. 2019. Temple Design in Six Early Śaiva Scriptures. Critical Edition and Translation of the Prāsādalakṣaṇa-portions of the Bṛhatkālottara, Devyāmata, Kiraṇa, Mohacūrottara, Mayasamgraha \& Pingalāmata. Collection Indologie, no. 138. Pondichéry: Institut Français de Pondichéry/École française d' Extrême-Orient.

Mishra, R.N. 1993. "The Saivite Monasteries, Pontiffs and Patronage in Central India." Journal of the Asiatic Society of Bombay 64-66: 108-124.

Mori, Masahide. 2005. "The Installation Ceremony in Tantric Buddhism." In From Material to Deity, Indian Rituals of Consecration, edited by Shingo Einoo and Jun Takashima, 199-240. Manohar: New Delhi.

Nandi, R.N. 1987. "Origin and Nature of Śaivite Monasticism: The Case of the Kālāmukhas." In Indian Society: Historical Probings, In Memory of D.D. Kosambi, edited by R.S. Sharma, 190-201. New Delhi: People's Publishing House.

Sanderson, Alexis. 1988. "Śaivism and the Tantric Traditions." In The World's Religions, edited by S. Sutherland, et. al., 66o-704. London: Routledge and Kegan Paul.

Sanderson, Alexis. 1995. "Meaning in Tantric Ritual." In Essais sur le Rituel III, edited by 
A.-M. Blondeau and K. Schipper, 15-95. Bibliothèque de l'École des hautes études, Sciences religieuses, vol. cII. Louvain-Paris: Peeters.

Sanderson, Alexis. 2001. "History Through Textual Criticism in the Study of Śaivism, the Pañcarātra and the Buddhist Yoginītantras." In Les Sources et le temps, edited by François Grimal, 1-47. Publications du département d'Indologie, no. 91. Pondichéry: Institut Français de Pondichéry/École française d'Extrême-Orient.

Sanderson, Alexis. 2004. "Religion and the State: Śaiva Officiants in the Territory of the Brahmanical Royal Chaplain (with an appendix on the provenance and date of the Netratantra)." Indo-Iranian Journal 47: 229-30o.

Sanderson, Alexis. 2007. "The Śaiva Exegesis of Kashmir." In Melanges tantriques a la memoire d'Helene Brunner/Tantric Studies in Memory of Helene Brunner, edited by Dominic Goodall and Andre Padoux, 231-442, 551-582 (bibliography). Collection Indologie, no. 106. Pondichéry: Institut Français de Pondichéry/École française d'Extrême-Orient.

Sanderson, Alexis. 2009. "The Śaiva Age:The Rise and Dominance of Śaivism during the Early Medieval Period." In Genesis and Development of Tantrism, edited by Shingo Einoo, 41-35o. Institute of Oriental Culture Special Series, no. 23. Tokyo: Institute of Oriental Culture, University of Tokyo.

Sears, Tamara I. 2007. "Śaiva Monastic Complexes in Twelfth-Century Rajasthan: The Pāśupatas and Cāhamānas at Menāl." South Asian Studies 23: 107-126.

Sears, Tamara I. 2014. Worldly Gurus and Spiritual Kings, Architecture and Asceticism in Medieval India. New Haven; London: Yale University Press. 